\title{
Exploring Teacher Candidates' Views on Educational Reform
}

\author{
By Pervin Oya Taneri*
}

\begin{abstract}
The continuation and success of educational reforms need teachers' awareness on those reforms. When the people do not understand educational reforms, vital educational reforms will fail to get approved or be implemented. The present study was an attempt to explore the teacher candidates'views on educational reform. 36 prospective teachers participated in this study. The data were collected in the 2014-2015 academic year by using semi-structured interviews. The findings of this study revealed that the majority of prospective teachers are not familiar with the reasons of recent educational reform. A significant majority of the respondents had the view that the Educational reforms bring little benefits and in some cases damage both the teachers and the students. The study concluded that a well-organized change is essential in teacher education programs in order to encourage teacher candidates to be involved critically in, and with, the educational system, in which they will work.
\end{abstract}

Keywords: benefits of educational reform, educational reform, educational reform in Turkey, teacher candidates, teacher education

\section{Introduction}

Resembling many organizations educational institutions should be constantly checked in order to determine aspects in need of improvement (Credaro, 2006). While the main purpose of education has evolved according to the needs of society throughout the ages, the general aim has been to contribute to economic development and to improve the living standards of the people. Each society wants to respond to the current needs of age by its education system (Amanchukwui \& Daminabo, 2014). Today the main purposes of education are to support learners in developing the skills, the knowledge, and the dispositions that will allow them to be responsible, contributing members of their community, to enable them to be life-long learners and effective citizens, and to help them become independent, active, and self-regulated learners (Arends, 2004; Cohen, 2001; Erdem \& Demirel, 2002).

The world becomes increasingly complex because of quick changes. As a result, the education system is faced with new demands and new challenges (Bar-yam, Rhoades, Sweeney, Kaput, \& Yaneer Bar-Yam, 2002). One of the

\footnotetext{
${ }^{*}$ Assistant Professor, Cankiri Karatekin University, Turkey.
} 
main motives behind this change is technology, and sometimes the technological innovations play an important role in the design and delivery of education (Kuboni, Kinshuk, Mackintosh, Victor, Webb, \& West, 2012). Since globalization can be conceived as a consequence of modern science and new technology, the escalating globalization process has an impact on the current educational reform (Garm \& Karlsen, 2004). There is an international agreement that educational reform becomes inevitable as a consequence of social events, cultural and economic needs and technological developments. Educational reform movements are envisioned to meet the needs of the society and the world, to progress socio-economic development, close international achievement gaps and to decrease inequality through planned changes in many issues related to education such as curricula, instructional approaches, educational philosophies, teaching and learning methodologies, and administrative processes (Akşit, 2007; Flouris \& Pasias, 2003; Huang, 2004). It appears that the fundamental aim of educational reform is to improve the quality of education (Flouris \& Pasias, 2003; Huang, 2004), and answer some societal problems.

Educational reform may sometimes happen on a large-scale, such as all the components of curricula: objectives, contents, instructional methods, and assessments techniques, are changed and/or the education system is completely restructured. On the other hand, on a small-scale it has been focused on changing the name and/or duration of a course. Unless stakeholders understand the reasons of educational reform, even vital educational reform will fail to get approved or implemented. There are widespread difficulties that challenge the possibility of reform success in many countries. Numerous researchers maintained that the top-down manner of educational reforms, and the lack of understanding of stakeholders decrease the rate of acceptance of any change (Akşit, 2007; Duman, Baykan, Köroğlu, Yılmaz, \& Erdoğan, 2014; Grossman, Önkol, \& Sands, 2007; Türkan \& Grossman, 2011). Karam (2015) stated that there are five common obstacles that prevent the effective implementation of reforms. 1. top-down and forced reforms, 2. insufficient information about the reforms, 3. inadequate time to implement those reforms, 4. insufficiency of allocated resources, and 5. lack of continuous professional development opportunities.

Schools as flexible and responsive learning organizations are sensitive to social, economic, and political circumstances. Explicitly, the constituents of the schools are not restricted to those in the physical boundaries of the school. Several groups such as families, employers and social welfare associations have anticipations from schools. The whole community is affected by the educational arrangements and processes. Therewithal, the constituents of the schools may have opinions about the educational innovations that obstruct to the implementation of innovations (Credaro, 2006).

Dissatisfaction and distrust in the educational reform is a global phenomenon. Education reform does not only mean to put into practice most recent policies, but also to change the culture of the classrooms, schools, districts, and universities. If the stakeholders- teachers, students, principals, 
parents, and other members of society who are affected by educational reformdo not respect and/or understand educational reforms, even the wellintentioned change initiatives will rather harm than benefit education. Therefore, understanding the views of stakeholders is necessary to ensure the acceptance, maintenance and success of educational reform.

Since the success of educational reforms largely depends on the adoption of and willingness to implement these reforms, teacher education programs play a crucial role in producing teachers who have awareness about current educational reforms. The teacher education programs are expected to reassure teacher candidates to be involved critically in, and with, the educational system, in which they will work. Specifically, the teacher candidates' consciousness of educational reforms has a great affect on the effective implementation of educational reforms and the improvement of the quality of education (Duman, Baykan, Köroğlu, Yılmaz, \& Erdoğan, 2014). The teacher candidates should learn how to analyze reform movements and investigate new, forward-leaning notions in education, so as to encourage their students to achieve better results by improving teaching approaches, and the instructional materials they use. However, one of the biggest challenges that teacher education programs cope with is to inspire teacher candidates to reconceptualize some fundamental educational issues and their role in the system (Asif, 2013).

Research related to reform movements usually focuses on the perspectives of the teachers and academicians who are professionally involved in education (e.g. Datnow \& Castellano, 2000; Erdoğan, Kayır, Kaplan, Aşık, \& Akbunar, 2011; Spillane, Reiser, \& Reimer, 2002). There are very few studies that focus on the perspectives of teacher candidates on reform movements or their attitudes toward educational reform (Ekiz \& Yiğit, 2007; Uluçınar-Sağır \& Karamustafaoğlu, 2011). Since teachers and academicians are directly affected by educational reform they compulsorily conscious about its effects for their own practice. On the other hand, teacher candidates have interpreted the educational reform with student perspective up to now. In this study teacher candidates have been considered as both students and teachers. How they understand, interpret, and adopt educational reform would influence their instructional approaches. In order to guide, support, and inspire teacher candidates in their professional development, and encourage them to make decisions based on educational reform, their consciousness should be exposed. Consequently, this article aims to uncover the awareness and views of secondary school teacher candidates about educational reform. Given this background, the article focuses on teacher candidates' views on educational reform. This article tries to find answers to the following questions:

1. How do the teacher candidates make sense of the concept of education reform?

2. What do the teacher candidates think about when or in which cases educational reforms are required? 
3. Who according to the teacher candidates, benefits from educational reforms?

\section{Methodology}

Qualitative research methods are very functional to realize how to understand a phenomenon (Krathwohl, 2009). Therefore, qualitative research methodology was used in this study with the purpose of gathering in depth information about the awareness and views of teacher candidates about educational reform.

\section{Participants}

Data were collected from a small sample, since interviews are time consuming. The participants of this study were 36 teacher candidates from the teacher certification program at Cankiri Karatekin University, in Turkey. The teacher certification programs have been offered as an alternative to teacher education faculties. These programs have been prepared for graduates of literature and arts faculties, and generally cover whole academic year (i.e. two semesters with 14 weeks). Their main purpose is to help teacher candidates gain an understanding of classroom management, child development and learning, student assessment, lesson planning, instruction methods and counseling (Taneri, Nayir, \& Mcnamara, 2014).

Participants were all between the ages of 21-31 and only 4 of them were males and 32 were females. All participants completed a Bachelor's degree in different departments such as sociology, philosophy, history, geography, Turkish language and literature, physics, chemistry, biology, fine arts, and mathematics. Only two of them will continue to graduate education.

\section{Data Collection}

The data were collected during the 2014-2015 academic year by using semi-structured interviews. The researcher developed an interview guide that consists of list of questions and topics that need to be covered during the conversation. The semi-structured interview form involves three demographic questions and six open-ended questions to get the research data from the respondents. Interview questions were prepared after reviewing the literature and obtaining expert opinions. Interviews were tape-recorded after getting consent from the participants and these tapes were transcribed for data analysis.

In this study data were collected when no original or appropriate information comes out, that is until data saturation was reached (Flick, 2002; Morse, 1995), so as to reveal a range of pertinent perspectives, and to pinpoint meaningful generalizations.

\section{Data Analysis}


The data collected were analyzed through qualitative techniques. That is, data were analyzed using a coding procedure. Data analysis was a consecutively winnowing process. Explicitly, during the analysis process the researcher gradually focused on and selected the important. Throughout the coding process, descriptive words or phrases were assigned to the transcribed data. Similar, repeated, and/or interrelated information was identified. The unusual answers are supposed to hold valuable information on the theme (Hammersley \& Atkinson, 2007), so the words used by participants were also used as codes.

In order to supply a concrete and visual analysis, the data were content analyzed according to the classic approach (Krueger \& Casey, 2009). The transcribed data were checked and coded by two researchers separately, to validate precise depiction (Lincoln \& Guba, 1985). The codes and categories were compared and discussed by the researchers with the intention of decreasing personal bias; in so doing, increasing researcher consistency (Denzin, 2009). Finally, a narrative summary was written for each of the areas of enquiry.

\section{Findings and Discussions}

Data were analyzed, interpreted, and presented through three sub-headings in accordance with the research questions. These sub-headings are meaning, necessity and benefits of educational reform.

\section{What is the Meaning of Educational Reform?}

The respondents were asked the meaning of educational reform. It was recognized that the participants loaded education reform with a variety of meanings such as: innovation, development, correction, improvement and (radical) change. On the other hand, several respondents mentioned the negative and politic aspects of educational reform. They stated that educational reforms are proposals to make unimportant changes in the educational system. Those proposed reconstructions of the educational system do not have the potential to lessen inequalities in society. The following excerpt proves this finding:

"Educational reform reminds me of politics. Namely, educational reform refers to modifying education mostly for political reasons. Educational reforms cannot decrease inequalities... They are trivial changes that are carried out to deceive and put off the public." (\#12)

This finding is consistent with Akşit (2007). He stated that educational reform movements in Turkey have been fairly disconnected, and have not focused on fundamental educational issues. Many perfunctory and imprecise changes were made in the past, but they did not create a dramatic effect on the 
education system.

To obtain more detailed information they were asked to give examples of educational reforms focused on improving the quality of education. A surprising result emerged, that most of the teacher candidates were not aware of many of the educational reforms. The results indicate that most of the respondents reported that the adoption of the Latin alphabet (which was enacted in 1928) and the Law on Unification of National Education (which was enacted in 1924) were the most remarkable educational reforms. One of the teacher candidates pointed out that:

"I think the alphabet revolution was the best education reform actually carried out so far. Tevhid-i Tedrisat (the Law on Unification of National Education) was also one of the great educational reforms in Turkey." (\#27)

The reason for the acceptance of these reforms is the best in education might be their radical effects on the whole country. During the Ottoman Empire period, two different institutions provide education: madrasa and local schools, and reading and writing were taught with the Arabic alphabet. Specifically, the Law on Unification of National Education provided unity in education in order to ensure the integrity of the nation's thoughts and feelings. It was seen as the first step towards the establishment of the secular Turkish education system (Topić \& Sremac, 2014). According to the OECD report (2005), the adoption of the Law on the Unification of Education, No. 430 was the primary most important reform around that time. This Law led to the democratization and the secularization of the education system. Consistent with this law all educational and scientific institutions were attached to the Ministry of National Education (Nohl, Akkoyunlu-Wigley, \& Wigley, 2008). In the same way, with the adoption of the Latin alphabet the literacy rate has increased very dramatically (the literacy rate has risen from $1 \%$ to $90 \%$ ).

Teacher candidates were also asked about their thoughts on the current educational reform in Turkey. It was seen that teacher candidates were confused about current reforms; they especially did not understand the $4+4+4$ system, smart boards' installation to all schools, the extension of the duration of high schools from 3 to 4 year, and the distribution of Tablet computers to all students. The following excerpts are a few examples among many:

"I think tablet computers and smart boards negatively impacted the students. Students were not productive individuals any more, they become only consumers." (\#7)

In 2012 a number of changes were made in the Turkish education system. The new system, called as $4+4+4$ education system, extends compulsory education from 8 years to 12 years. The government lowered the age of starting school to 5.5 as part of new education legislation. The following excerpts illustrate the confusions of teacher candidates: 
"I never understood how the 4+4+4 education system worked." (\#14)

"I wonder who has the benefit from the 4+4+4 education system." (\#19)

"As a consequence of the $4+4+4$ education reform, the image of the Turkish education system is adversely affected, and the privatization process of education is accelerated." (\#32)

This finding is parallel with the literature. Several researchers asserted that many of the teacher candidates (Duman, Baykan, Köroğlu, Y1lmaz, \& Erdoğan, 2014), teacher educators (Grossman, Önkol, \& Sands, 2007) and educational leaders (Türkan \& Grossman, 2011) criticized the 4+4+4 education system. In his study Sökmen (2012) claimed that, since this new system premeditates that at the end of the 4th grade all students are expected to be placed in different school according to their academic achievements, it increases inequity in education and naturally leads to social injustice. That is, this early vocational separation pushes lower income and low-academic success students to attend poorer performing and less desired vocational schools, doesn't allow school choice or better education, and reduces the possibility of continuing graduate education.

A considerable amount of teacher candidates stated that none of the educational reforms in Turkey were successful. On the other hand, a number of of the teacher candidates thought that the distribution of free textbooks to students, the extension of compulsory education from 8 years to 12 years, increasing the schooling rate of girls, and ensuring freedom of dress for students were effective educational reforms in Turkey.

\section{When or in Which Cases Educational Reform Is Needed?}

The teacher candidates stated that educational reforms have been made for various particular motives such as rapid technological developments, changing and increasing demands of society, deficiencies in curricula, fails in international exams (i.e. PISA), increasing academic failure, and the establishment of a new government.

It was discovered that many of the respondents think that advances in technology force education systems to change. This finding shows similarities with the research of Kuboni et al. (2012). They also claimed that technology is a significant motive behind change, and it has a great impact on improvements in educational plans. The following is one of the quotes that exemplifying this conclusion:

"With developments in technology, education programs are forced to change. Therefore, educational reforms are needed." (\#4) 
Some of the respondents asserted that educational reform and government changes are simultaneously. Educational reform is considered as the top priority for any new government in Turkey. Incumbent politicians have been trying to implement their own education policy. They stated that educational reforms are carried out in accordance with the efforts to sustain the management of politicians. The following excerpt is a good example to this theme:

"The governments in order to hold the power of management in their hands make several educational reforms that ensure to keep the government in office." (\#14)

\section{Who Benefits from Educational Reform?}

The findings of this study revealed that the majority of the prospective teachers unaware of the rationale and benefits of recent educational reforms. Nearly all of the teacher candidates think that the real purposes of educational reform are very different from those expressed. Specifically, the respondents claimed that major educational reforms carried out in recent years in Turkey were made to meet political needs, rather than to meet the needs of the education system. The following quote displays this view:

"Of course, politicians benefit from educational reform. They use educational reform movements to persuade voters for political cooptation. For instance, before elections in order to get political advantage politicians generally suggest teaching professions as a form of employment. They committed to make fundamental reforms related to teacher appointments. Unfortunately, after the elections the promises were forgotten." (\#19)

This finding coincides with Akşit's (2007) study. He stated that since the educational reforms were made to obtain political benefits, they did not change the education system considerably. On the contrary, Corrales (1999) asserted that quality education reforms, do not deliver direct, profound political gains to governments. Since the benefits of educational improvements are not observed in short-term, educational reforms have not been considered as a crucial issue by governments.

A significant majority of teacher candidates supported that the educational reform brings little benefits to the stakeholders. In some cases, educational reforms are motivated by interests other than educational development and may really be harming students, teachers, and public schools. The following quotes clearly demonstrate this interpretation:

"Theoretically the educational reforms have been focused on developing better education opportunities for students. I think the opposite. I mean students are negatively affected by the educational reforms. For example, high school education was extended from three years to four years when I 
was a high school student. How could this benefit me personally? No benefits! I just lost one year of my life. I began to work with a one-year delay. Nobody knows how the last year (fourth year) contributes to student success." (\#9)

"When the school starting age lowered to $5.5 \mathrm{my}$ brother started primary school. He had lots of problems. Now he hates school." (\#33)

Respondents stated that educational reforms have been done with the effect of global market economies, rather than resulted from and addressed needs of the society. The majority of the respondents criticized the commercialization of education. The following quotations show teacher candidate's thoughts about educational reforms and the privatization of education:

"Education has been converted into a commodity through recent educational reform movements. Lots of educational institutions in Turkey are not operated by the private sector anymore. In my opinion educational reforms do not attempt to reinforce public education." (\#3)

"...with the current educational reforms, education has been considered as a commercial source of profit." (\#4)

Literature supports this finding that the rise of the global market economy and rigorous reforms of education generate new perspectives on the organization and the effectiveness of the education system (Garm \& Karlsen, 2004).

\section{Conclusions}

In this study, the process of educational reform in Turkey was investigated by evaluating the views of teacher candidates. It was seen that teacher candidates may not always be clearly aware of educational reform, or able to analyze its possible benefits. Teacher candidates should recognize that education is not only the transfer of knowledge to the students, but also a dynamic process in which the teachers should actively participate in the decision making, and curriculum implementation process.

Educational reform may be needed due to many different reasons. Current educational reforms in Turkey aim at equalizing some societal troubles, such as gender-based inequalities, continuing teacher shortage, and perceived ineffectiveness. However, the purposes of current educational reforms and the beneficiaries from them are not generally well understood by teacher candidates. Lack of understanding of educational reform causes discrepancies in the implementation of its requirements. If educational reforms are not well implemented, this can cause huge wastage of money, human resources, and lost 
potential (Credaro, 2006).

It was recognized that one of the barriers that hinder the adoption of educational reform is that, it has been in an unstable structure. That is, educational reforms have been made very frequently in Turkey. Without waiting for the results of an educational reform, new amendments introduced.

The results also exposed that almost all teacher candidates called the adoption of the Latin alphabet and the Law on Unification of National Education as the best educational reforms. The reason why teacher candidates remember only these two reforms might be that the content of the courses in teacher education programs were included in these topics. In the same way, many of the respondents mentioned and criticized the 4+4+4 education system. According to Duman et al. (2014), the recurrent and long appearance of it in the media had increased public interest on this issue.

The teaching career is very crucial, not only to educate the school age children but also to change the future of the society. It is obvious that the successful reforms require insightful learning and change of teachers (Wheatley, 2002). So, understanding what the teacher candidates know-and what they do not know -what works about educational reform seems not only a good beginning but indeed it is one of the necessary steps to be taken in teacher education programs. So as to implement the education reform effectively the teacher education programs should include some courses or topics that make prospective teachers conscious about them.

The study is limited in its findings in the following ways: The participants of the study are limited to teacher candidates from one teacher education program. Moreover, since this study was based on voluntary participation, unfortunately, a few male teacher candidates agreed to participate. It was seen in the literature that the research topics that females prefer to join are different than those of males. While females prefer to participate in studies on sharing feelings and moods, males prefer studies related to competition and authority (Signorella \& Vegega, 1984; Tannen, 2007; Whitley \& Wiederman, 2002). Therefore, the results of this article are limited to data collected from the participants of the teacher certification program.

One strong suggestion from this study is that teacher educators need to create opportunities for teacher candidates to review and discuss current educational reforms. In the light of the findings of this article, teacher educators and education policy makers may reconsider the importance of the teacher candidates' existing knowledge and awareness on educational reform to its realization. This article concluded that a well-organized change is essential in teacher education programs in order to encourage teacher candidates to involve critically in, and with, the educational system, in which they will work.

It is hoped that the results of this article will contribute to the literature on educational reform. The findings of this study should be beneficial to teacher educators and education policy makers to develop a deeper insight on the importance of increasing the teacher candidates' awareness about the educational reform. 


\section{Acknowledgments}

My thanks go to all the teacher candidates who contributed to this study.

\section{References}

Akşit, N. (2007). Educational reform in Turkey. International Journal of Educational Development, 27 (2), 129-137.

Amanchukwui, R. N., \& Daminabo, D. (2014). Bringing about change in the school system: application of Fullan's six secrets of change as a bedrock of educational change in the Nigerian educational system. International Journal of Educational Foundations and Management, 2 (1), 83-100.

Arends, I.R. (2004). Learning to teach. New York: MrGraw Hill.

Asif, F. (2013). Prospective teachers' beliefs about concepts of teaching and learning. International Journal of Academic Research and Reflection, 1 (1), 41-51.

Bar-Yam, M., Rhodes, K., Sweeney, L.B., Kaput, J., \& Bar-Yam, Y. (2002). Complex systems perspectives on education and the education system. Cambridge, MA: New England Complex Institute.

Cohen, J. (2001). Caring classrooms/intelligent schools: the social emotional education of young children. New York: Teachers College Press.

Corrales, J. (1999). The politics of education reform: bolstering the supply and demand: overcoming institutional blocks. Educational Reform and Management Series, 2 (1). Washington, D.C.: World Bank.

Credaro, A. (2006). Innovation and change in education. Warrier Librarian. Retrieved December 12, 2014 from http://bit.ly/1SfQ911

Datnow, A., \& Castellano, M. (2000). Teachers' responses to success for all: how beliefs, experiences, and adaptations shape implementation. American Educational Research Journal, 37, 775-799.

Denzin, N. K. (2009). The Research Act in Sociology: A theoretical introduction to sociological methods. Piscataway, NY: Transaction Publishers.

Duman, G., Baykan, A.K., Köroğlu, G.N., Yılmaz, S., \& Erdoğan, M. (2014). An investigation of prospective teachers' attitudes toward educational reforms in Turkey. Educational Sciences: Theory \& Practice, 14 (2), 609-628.

Ekiz, D., \& Yiğit, N. (2007). Öğretmen adaylarının öğretmen eğitimindeki modeler hakkında görüşlerinin program ve cinsiyet değişkenleri açısından incelenmesi [Examination of the teacher candidates' views on the teacher education models in terms of program and gender]. Türk Eğitim Bilimleri Dergisi, 5 (3), 543-557.

Erdem, E., \& Demirel, O. (2002). Constructivism in curriculum development. Hacettepe University Education Faculty Journal, 23, 81-87.

Erdoğan, M., Kayır, Ç. G., Kaplan, H., Aş1k, Ü. Ö., \& Akbunar, Ş. (2011). Teachers' views on newly developed curricula: A content analysis of research between 2005 and 2011. Paper presented at the First International Conference on Curriculum and Instruction, Anadolu University, Eskişehir, Turkey.

Flick, U. (2002). An introduction to qualitative research. London: Sage.

Flouris, G., \& Pasias, G. (2003). A critical appraisal of curriculum reform in Greece (1980- 2002). European Education, 35 (3), 73-90. 
Hammersley, M., \& Atkinson, P. (2007). Ethnography: Principles in Practice. (3rd ed.). London: Taylor and Francis e-Library.

Huang, F. (2004) Curriculum reform in contemporary China: seven goals and six strategies. Journal of Curriculum Studies, 36 (1), 101-115.

Garm, N., \& Karlsen, G.E. (2004). Teacher education reform in Europe: The case of Norway; trends and tensions in a global perspective. Teaching and Teacher Education, 20, 731-744.

Grossman, G. M., Önkol, E. P., \& Sands, M. (2007). Curriculum reform in Turkish teacher education: Attitudes of teacher educators towards change in an EU candidate nation. International Journal of Educational Development, 27, 138150.

Karam, R. (2015). Implementing educational reform to enhance school performance. The RAND Blog. Retrieved December 22, 2015 from http://bit.ly/1JtK9yg

Krathwohl, D.R. (2009). Methods of educational and social science research: an integrated approach. Long Grove, Illinois: Waveland Press. Inc.

Kuboni, O., Kinshuk, A., Lentell, H., Mackintosh, W., Victor, L., Webb, R., \& West, P. (2012). Achieving Development Goals: Innovation in Education and Development. Retrieved December 9, 2014 from http://bit.ly/1NZVg6h.

Krueger, R. A., \& Casey, M. (2009). Focus groups: A practical guide for applied research. (4th ed.). Los Angeles, CA: Sage.

Lincoln, Y. S., \& Guba, E. G. (1985). Naturalistic inquiry. Beverly Hills, CA: Sage.

Morse, J. M. (1995). The significance of saturation. Qualitative Health Research, 5(3), 147-149.

Nohl, A. M., Akkoyunlu-Wigley, A., \& Wigley, S. (2008). Education in Turkey. New York/Münster: Waxmann Publishing.

OECD (2005). Basic education in turkey background report. Paris: Organization for Economic Co-operation and Development.

Signorella, M. L., \& Vegega, M. E. (1984). A note on gender stereotyping of research topics. Personality and Social Psychology Bulletin, 10 (1), 107-109.

Spillane, J. P., Reiser, B. J., \& Reimer, T. (2002). Policy implementation and cognition: reframing and refocusing implementation research. Review of Educational Research, 72, 387-431.

Taneri, P.O., Nayır, K.F., \& Mcnamara, G. (2014). Teacher candidates' attitudes towards the teaching profession-worrying trends. Turkish Studies-International Periodical for the Languages, Literature and History of Turkish or Turkic, 9 (11), 529-545.

Tannen, D. (2007). You Just Don't Understand: Women and Men in Conversation. New York: Ballantine Books.

Topic, M., \& Sremac, S. (2014). Europe as a multiple modernity. In M. Topic \& S. Sremac (Eds.), Europe as a Multiple Modernity: Multiplicity of Religious Identities and Belonging. Newcastle Upon Tyne: Cambridge Scholars Publishing.

Türkan, S., \& Grossman, G. (2011). The teacher educators and leaders as agents of change in a teacher education activity system; the reform-in-the-making in Turkey. International Online Journal of Educational Sciences, 3(1), 1-29.

Uluçınar-Sağır, Ş., \& Karamustafaoğlu, O. (2011). Fen bilgisi öğretmen adaylarının program geliştirme sürecine ilişkin bilgi düzeyleri [Science teachers' knowledge levels regarding the curriculum development process]. Celal Bayar Üniversitesi Ë̆itim Fakültesi Dergisi, 1(1), 109-113.

Wheatley, K.F. (2002). The potential benefits of teacher efficacy doubt for educational reform. Teaching and Teacher Education, 18, 5-22. 
Whitley, B. E., \& Wiederman, M. W. (2002). Handbook for conducting research on human sexuality. New Jersey: Lawrence Erlbaum Associates. 
